\title{
Investigating Students’ Computational Thinking Skills on Matter Module
}

\author{
Noraini Lapawi ${ }^{1}$, Hazrati Husnin ${ }^{2}$ \\ Centre of Teaching and Learning Innovation \\ National University of Malaysia \\ Bangi, Malaysia
}

\begin{abstract}
The revolution of the fourth industrial has impacted most aspect of our life and demanding a paradigm shift including education. It has become to our attention that there is a need to inculcate complex problem-solving skills among youth to equipped them to face the challenges in the era of digital technology. To fulfill the needs, computational thinking was introduced in school curriculum in Malaysia in 2017. It is still rather new, and this creates opportunity to understand how computational thinking can best be integrated in teaching and learning. In this study, we developed a module for a science topic, Matter and examine its impact on computational thinking skills on 65 students at secondary level. The computational thinking skills integrated in this study were abstraction, decomposition, algorithm, generalization, and evaluation. A quasi-experimental method was employed, and the ANCOVA result showed that there was no significant difference between control and treatment group on computational thinking skills. However, the score means for each of the computational thinking skills for both groups, showed that three skills in the treatment group were higher than the control group. The three computational thinking skills were decomposition, evaluation, and algorithm. This study suggested that CT involved mental process and proper planning is crucial to integrate computational thinking skills as teaching and learning is very contextual in nature.
\end{abstract}

Keywords-Computational thinking skills; problem solving skill; teaching and learning; decomposition; evaluation; algorithm; science module; matter; secondary level students

\section{INTRODUCTION}

The 4th Industrial Revolution has a global impact on human life, economic and the social landscape. The rapid growth of technology requires a paradigm shift in various fields including education, especially in shaping a generation to become competent, resourceful, and competitive to cope with the challenges in the near future. It is crucial to ensure the education given to the young generations is robust and meeting these demands. The World Economic Forum (WEF) stated complex problem-solving skill as one of the highest percentages out of nine skills outlined in the list of skills in demand for the future workplace [1]. Therefore, in most of development countries such as Malaysia, inculcating critical thinking and problem-solving skills is one of the prime agenda in education sector especially for the critical subjects such as science and mathematics [2]. By doing so, students can apply science knowledge to make decisions and solving complex problems in the context of real life creatively and innovatively.

This study is fully funded by Dana Penyelidikan FPEND, GG-2019-014.
Knowing the high demands, problem solving skills has been introduced in most of curriculum system at the early stage of school. One of the approaches used is via computational thinking (CT). CT has been known as an approach that has been proven effective in helping to improve students' problemsolving skills using the concepts of computer science [3]. The common concepts of CT are decomposed, pattern recognition, abstraction, algorithm, logical reasoning, and evaluation. These concepts can be used not just to formulate problem but also to produce an automated solution [4]. Thus, the approach of applying CT skills in teaching and learning is seen to have the potential to produce students who have good problem-solving skills. This is in line with the intention to fulfill the needs for the fourth Industrial Revolution. However, the implementation of CT in Malaysia's education is rather new, and it is still unclear how CT can best be integrated in teaching and learning. Therefore, this study aims to examine the CT approach used in teaching and learning of Matter topic and the impact on students' CT skills. This study hypothesized that there is no significant difference in the mean score of the computational thinking skills test between the treatment and control groups $\left(\mathrm{H}_{01}\right)$. This paper begins by discussing about $\mathrm{CT}$ in teaching and learning in global context and scoping down to Malaysia context. The Matter module and its implementation in this study is also discussed, followed by the methodology employed and discussions on the findings.

\section{LITERATURE REVIEW}

\section{A. Computational Thinking in Teaching and Learning}

Computational thinking involves a systematic thought processes in solving problems based on computer science concept i.e. programming concept such as decomposition, abstraction, and algorithmic thinking [5]. According to [5], CT skill is seen as a necessity for every individual in today's digital era. Although computational thinking is an approach to problem-solving that normally being associated to the use of computers, the process of using mental skills is more prominence rather than solely relying on just computer [6]. Through integrating CT components such as decomposition and abstraction in the ideation process of developing solutions, creativity and innovation can be encouraged [7].

Exam-oriented and teacher-centered has been the practice for quite a while in most context of our education system. Through this practice, the learning approach emphasize memorizing rather than developing full understanding of the topic [8]. In addition, the teacher-centered or some may refer to 
as conventional approach is a kind of learning approach that emphasizes on the content and achievement [9]. Thus, the learning itself has become less meaningful. Therefore, the conventional approach needs to be transformed into a studentcentered approach by integrating technology in the process of learning [10]. In relation to inculcating computational thinking skills, this could be done through activity that involved plugged-in activity such as using programming [11]. In addition, the skills on coding or programming is also crucial in the future digital workforce [12]. In relation to this study, computational thinking is a form of skill that is suitable to be practiced by all students [13]. Thus, the concepts of computational thinking used in this study is decomposition, algorithm, abstraction, evaluation, and generalization.

\section{B. Computational Thinking in Malaysia}

In the context of education in Malaysia, computational thinking began to be offered in the curriculum since 2017 in some subjects such as Information Communication Technology (known as TMK) at primary level and Basic Computer Science (known as ASK) at secondary level. In this subject, students were exposed to the basic components of computational thinking such as decomposition, algorithm, and abstraction [14]. It could be said that the implementation of CT in Malaysia is still new and the dissemination of CT knowledge especially among teacher is still in progress. For example, a study showed that there was a misconception among teachers towards the concept of CT and its integration in teaching and learning [15]. Furthermore, a study also showed the low level of concern among teachers on applying CT in teaching and learning in Malaysia [16] albeit other study showed there were positive attitude among teachers towards the implementation of CT in the curriculum [17]. The inconsistency of findings presented in these studies described there is more need to be done regarding CT research area. On the other hand, this also raised opportunity for further study especially on how CT can best be integrated in teaching and learning. For example, a study by [18] showed that the CT skills among science students in one of district in Malaysia is low.

\section{MATTER MODULE}

The content covered in the module used in this study is Matter. The module emphasized group activity and creating opportunity for the students to engage in the learning activity and solving problem. The activities require students to solve problems using computational thinking skills represented by a simple programming using Scratch and hands-on activities. During the process, students can learn from their peers as they engage during the group work. As such, cooperative learning was applied, and scaffolding occurred between students and students and teachers with students and this helped those in the zone of proximal development [19].

The theoretical underpinned the design of learning activity in the module was based on Constructionism theory [20]. The theory emphasizes the construction of a new idea can be developed if students are able to produce artifact that is meaningful and shareable among their peers. In this module, the idea of learning by making was instilled and students were challenged to used the knowledge gained to develop a new complex idea, which in this case the programming project that they produced [21]. The activity in the module allowed students to integrate decomposition, algorithm, abstraction, generalization, and evaluation when explaining the changes in states of matter through Scratch program.

\section{Methodology}

This study employed a quasi-experimental method to examine the effectiveness of CT approach integrated in Matter module in developing students' CT skills. There were 65 participants participated in this study. They were divided into two group as described in Table I. The control group received a conventional approach intervention, while treatment group received CT Matter Module as intervention. Before the study takes place, teachers were given three days training on the module as well as training on Scratch application. The intervention for both control and treatment group took place for five weeks. The instrument used to measure CT skills was Computational Thinking Skills Test (UKPK) for both groups. The UKPK test were administered both group before and after the intervention.

The UKPK was developed by adapting Bebras CT Task rubric. There was a total of 15 items in the UKPK in a form of multiple-choice questions ranging from easy, moderate, and difficult question. The UKPK were administered to the participants in control and treatment group during pre-test to identify the level of students' existing CT skills and to ensure the homogeneity of both groups. The UKPK instrument again were administered to both group after they received the intervention. Table II showed the details of the UKPK instrument and the items.

Before you begin to format your paper, first write and save the content as a separate text file. Keep your text and graphic files separate until after the text has been formatted and styled. Do not use hard tabs, and limit use of hard returns to only one return at the end of a paragraph. Do not add any kind of pagination anywhere in the paper. Do not number text headsthe template will do that for you.

TABLE I. THE INSTRUMENT AND THE INTERVENTION

\begin{tabular}{|l|l|l|l|}
\hline \multirow{2}{*}{ Group } & \multicolumn{3}{|c|}{} \\
\cline { 2 - 4 } & Pre-Test & Intervention & Post-Test \\
\hline $\begin{array}{l}\text { Control } \\
(\mathrm{n}=31)\end{array}$ & $\begin{array}{l}\text { Computational } \\
\text { Thinking Skills Test } \\
\text { (UKPK) }\end{array}$ & $\begin{array}{l}\text { Conventional } \\
\text { approach }\end{array}$ & $\begin{array}{l}\text { Computational } \\
\text { Thinking Skills } \\
\text { Test (UKPK) }\end{array}$ \\
\hline $\begin{array}{l}\text { Treatment } \\
(\mathrm{n}=34)\end{array}$ & $\begin{array}{l}\text { Computational } \\
\text { Thinking Skills Test } \\
\text { (UKPK) }\end{array}$ & $\begin{array}{l}\text { CT Matter } \\
\text { Module }\end{array}$ & $\begin{array}{l}\text { Computational } \\
\text { Thinking Skills } \\
\text { Test (UKPK) }\end{array}$ \\
\hline
\end{tabular}


TABLE II. THE ITEM OF UKPK INSTRUMENT

\begin{tabular}{|c|c|c|c|c|}
\hline \multirow{2}{*}{ No } & \multirow{2}{*}{ CT Skills } & \multicolumn{3}{|c|}{ Level of Difficulty } \\
\hline & & Easy & Moderate & Difficult \\
\hline 1 & $\begin{array}{l}\text { Abstraction, } \\
\text { Algorithm, } \\
\text { Decomposition }\end{array}$ & $\mathrm{O} 1$ & & \\
\hline 2 & $\begin{array}{l}\text { Algorithm, } \\
\text { Decomposition, } \\
\text { Evaluation }\end{array}$ & $\mathrm{O} 2$ & & \\
\hline 3 & $\begin{array}{l}\text { Abstraction, } \\
\text { Algorithm, Evaluation }\end{array}$ & $\mathrm{O} 3$ & & \\
\hline 4 & $\begin{array}{l}\text { Abstraction, } \\
\text { Algorithm, Evaluation }\end{array}$ & $\mathrm{O} 4$ & & \\
\hline 5 & Algorithm, Evaluation & & O5 & \\
\hline 6 & Algorithm & & O6 & \\
\hline 7 & $\begin{array}{l}\text { Generalisation, } \\
\text { Evaluation }\end{array}$ & & O7 & \\
\hline 8 & $\begin{array}{l}\text { Abstraction, } \\
\text { Algorithm, Evaluation }\end{array}$ & & O8 & \\
\hline 9 & $\begin{array}{l}\text { Abstraction, } \\
\text { Algorithm, Evaluation }\end{array}$ & & O9 & \\
\hline 10 & $\begin{array}{l}\text { Algorithm, } \\
\text { Decomposition, } \\
\text { Evaluation }\end{array}$ & & $\mathrm{O} 10$ & \\
\hline 11 & $\begin{array}{l}\text { Abstraction, } \\
\text { Algorithm, Evaluation }\end{array}$ & & $\mathrm{O} 11$ & \\
\hline 12 & Evaluation & & & $\mathrm{O} 12$ \\
\hline 13 & $\begin{array}{l}\text { Desomposition, } \\
\text { Generalisation, } \\
\text { Evaluation }\end{array}$ & & & $\mathrm{O} 13$ \\
\hline 14 & $\begin{array}{l}\text { Abstraction, } \\
\text { Decomposition, } \\
\text { Evaluation }\end{array}$ & & & $\mathrm{O} 14$ \\
\hline 15 & $\begin{array}{l}\text { Abstraction, } \\
\text { Generalisation, } \\
\text { Evaluation }\end{array}$ & & & O15 \\
\hline
\end{tabular}

\section{FINDINGS AND DiscUSSION}

\section{A. Findings}

The descriptive analysis for the pre-test showed that the UKPK score mean for treatment group is higher than the control group. The score means for the control group is $\mathrm{M}=$ 3.70 ( $\mathrm{SD}=0.58)$ meanwhile score means for the treatment group is $\mathrm{M}=3.79$ ( $\mathrm{SD}=0.59)$. Homogeneity analysis between the control group and the treatment group was also tested to determine whether there were differences in terms of CT skills before the intervention (treatment) was performed. This was done using an independent sample t-test and Levene test with the significance value of 0.05 .

Table III shows that the results of the Levene test for homogeneity of variance for UKPK pre-test. Levene test of the significance value for UKPK pre-test is 0.653 . Therefore, it can be assumed that the variance between control and treatment group is equal as the value $\mathrm{p}>0.05$.

Meanwhile the independent sample t-test showed there is no significant difference between the mean score of UKPK pre-test for control and treatment group. The result is presented in Table IV. This also explained that both control and treatment group are homogenic before the intervention take place.

The descriptive analysis for post-test showed that the UKPK score mean for treatment group is higher than the control group. Whereby the score means for control group, $\mathrm{M}$ is 3.74 ( $\mathrm{SD}=0.514)$. Meanwhile, the score means for treatment group, $\mathrm{M}$ is 3.88 ( $\mathrm{SD}=0.686)$. As for the score means for each of the CT skills for both groups, the result showed that three skills in the treatment group were higher than the control group. The three CT skills were decomposition, evaluation, and algorithm. The result is presented in Table $\mathrm{V}$.

Levene test was conducted after the intervention take place. Table VI shows the results of the Levene test for homogeneity of variance for UKPK post-test. The significant value for the Levene test is 0.299 ( $p>0.05)$. Therefore, it can be assumed that the variance between control and treatment group is equal.

To test the hypothesis $\mathrm{H}_{01}$, ANCOVA test was performed based on significant level of 0.05. The result is presented in Table VII.

TABLE III. LEVENE TEST FOR VARIANCE HOMOGENEITY (UKPK PRETEST)

\begin{tabular}{|l|l|l|}
\hline Source & F & Sig. \\
\hline UKPK (pre-test) & 0.204 & .653 \\
\hline
\end{tabular}

TABLE IV. INDEPENDENT T-TEST (UKPK PRE-TEST)

\begin{tabular}{|l|l|l|l|l|}
\hline Dependable Varaiable & $\mathrm{T}$ & $\mathrm{Dk}$ & Sig. & Mean difference \\
\hline UKPK (pre-test) & -.576 & 63 & 0.567 & -.084 \\
\hline
\end{tabular}

TABLE V. THE SCORE MEANS For CT SKILlS

\begin{tabular}{|l|l|l|}
\hline CT Skills & Intervention & Post-Test \\
\hline $\begin{array}{l}\text { Computational Thinking } \\
\text { Skills Test (UKPK) }\end{array}$ & $\begin{array}{l}\text { Mean (M) Control } \\
\text { Group }\end{array}$ & $\begin{array}{l}\text { Mean (M) Treatment } \\
\text { Group }\end{array}$ \\
\hline Decomposition & 0.774 & 0.853 \\
\hline Evaluation & 0.516 & 0.706 \\
\hline Abstraction & 0.871 & 0.765 \\
\hline Algorithm & 0.742 & 0.765 \\
\hline Generalisation & 0.839 & 0.794 \\
\hline
\end{tabular}

TABLE VI. LEVENE TEST FOR VARIANCE HOMOGENEITY (UKPK POSTTEST)

\begin{tabular}{|l|l|l|}
\hline Dependable Varaiable & F & Sig. \\
\hline UKPK (post-test) & 1.097 & .299 \\
\hline
\end{tabular}

TABLE VII. RESULT OF ANCOVA TEST FOR UKPK POST-TEST

\begin{tabular}{|l|l|l|l|l|l|l|}
\hline $\begin{array}{l}\text { Dependable } \\
\text { Varaiable }\end{array}$ & $\begin{array}{l}\text { Sum of } \\
\text { Square }\end{array}$ & $\mathrm{dK}$ & $\begin{array}{l}\text { Mean } \\
\text { Square }\end{array}$ & $\mathrm{F}$ & Sig. & $\begin{array}{l}\text { Partial } \\
\text { eta } \\
\text { squared }\end{array}$ \\
\hline $\begin{array}{l}\text { UKPK (post- } \\
\text { test) }\end{array}$ & 0.338 & 1 & 0.338 & 0.896 & 0.347 & 0.014 \\
\hline
\end{tabular}


Based on Table VII, there was no significant different for the UKPK post-test, $F(65)=0.896, p=0.347$, with a small effect size (partial $\eta 2=0.014$ ). Thus, the study failed to reject $\mathrm{H}_{01}$ hypothesis. However, based on the mean score of UKPK post-test, it was found that the treatment group outperformed the control group.

\section{B. Discussion}

Based on the findings, it could be said that the process of integrating CT skills does not take immediate effect. Findings from previous studies indicate that the process of applying computational thinking skills takes longer to obtain significant results, especially when using programming approach such as Scratch. This finding corroborates with a study conducted by [22] whereby allocating an hour in a week for CT intervention yields insignificant result. On the contrary, the studies by [23][24] allocated a longer period for CT intervention found to be significant. The effectiveness of a module might also being influence by the approach used by the teacher in carrying out the module. In this study, the approach used to teach CT was via plugged-in i.e. Scratch. The duration of training on the module and Scratch received by teachers in this study was short. Although [25] suggest CT training can be taught to teachers in a short training, it might work differently in this study especially for the teachers without computer science background. Although many studies have shown the effectiveness of using plugged-in approach to integrate CT skills [26], it is challenging for teachers without computer background to comprehend since CT components are closely related to computer science concept [27]. On another note, it could be argued that by delivering CT training via technology medium such as by using computer programming solely to learn CT might hinder one's awareness on the thought process of computational thinking while engaging with the programming activity. This could be one of the factors that contributed to the insignificant result. Scratch is just a tool to teach CT and not being able to realize that CT is a mental process and differentiate the affordances of Scratch in teaching CT will hinder the process of understanding the real concept of computational thinking [28]. In the end, students will end up creating Scratch projects but not being able to transfer those skills into different subject effectively. It is the role of a teacher to ensure students are aware of the thinking process involved while dealing with the activities in the module.

Although the finding of the study is insignificant, the findings of descriptive data show that the Matter Module is effective compared to conventional approach. This effectiveness can be seen through three of the five components of computational thinking integrated in the Matter Module have higher mean score. The findings of this study are in line with the study conducted by [29] for two CT skills, namely decomposition and algorithm. Whereas in this study, the decomposition, algorithms, and evaluations were achieved after using the Matter Module. The effectiveness of instilling CT skills in teaching and learning depending largely on the approach used by the teachers and the activity planned in associated to the CT skills. In this study, the decomposition skill was applied at the early stage by the participants in solving large problems to smaller problems. While algorithm skill was used in Scratch programming steps and evaluations were widely used throughout the Scratch project developed by the participants. It could be said that it is not a one size fits all as integrating CT skills in a learning activity is contextual. Although there are many CT concepts [5], not all can fit in with the content and learning activities. If the content is related to computer science or technical subjects, there are variety of CT concept can be integrated [30]. In the context of this study, the learning activities designed in this Matter module was more relevant to decompose, evaluation dan algorithm concept. This explained the higher means score of these three CT concepts as opposed to the other CT concepts integrated in the module, abstraction, and generalization.

\section{CONCLUSION}

It can be concluded that integrating CT requires a thorough planning albeit the opportunity it can brings specially to inculcate problem solving skills among students to fulfill the demand for the future workforce. This study suggest that instilling computational thinking skills require longer time to demonstrate meaningful findings in most cases. It is crucial to properly consider which CT skills are suitable to the context of the learning environment. Contextual here might be referred to the type of learning activity, the nature of the subject matter, and the facilities to support the delivery of the teaching and learning. On an important note, integrating CT in teaching and learning to foster problem solving skills need to be viewed as a mental process rather than the use of computer solely. The future extension of this study shall be considering the allocation of intervention time to see how it will affect the effectiveness and fostering CT skills among students.

\section{ACKNOWLEDGMENT}

The authors extend their appreciation to the Dana Penyelidikan FPEND at National University of Malaysia, GG2019-014 for funding this study.

REFERENCES

[1] World Economic Forum, The Future of Jobs Employment, Skills and Workforce Strategy for the Fourth Industrial Revolution, Growth Strategies, 2016.

[2] Kementerian Pendidikan Malaysia, Kurikulum Standard Sekolah Menengah, Dokumen Standard Kurikulum dan Pentaksiran Sains Tingkatan 3, Bahagian Pembangunan Kurikulum, Putrajaya: 2015.

[3] S. Kassan, K. F. Looi, and Y. M. Tham, Asas Sains Komputer Tingkatan 1, Kementerian Pendidikan Malaysia, Kuala Lumpur: 2016.

[4] Y. B. Kafai, and Q. Burke, “Computer Programming Goes Back to School,” Phi Delta Kappan, vol. 95, pp. 61-65, September 2013.

[5] J. M. Wing, “Computational Thinking," Communications of the Association for Computing Machinery (ACM), vol. 49(3), pp. 33-35, March 2006.

[6] E. N. Caeli, and A. Yadav, "Unplugged Approaches to Computational Thinking: a Historical Perspective,” TechTrends, vol. 64, pp. 29-36, July 2019.

[7] S. M. S. Azman, M. Arsat, and H. Mohamed, "The framework for the integration of computational thinking in ideation process," 2017 IEEE $6^{\text {th }}$ International Conference on Teaching, Assessment and Learning for Engineering, Hong Kong, pp.61-65, December, 2017.

[8] F. Rani, M. Mohammad, and S. Suslistyo, "Pengembangan multimedia simulatif kimia berbasis inkuiri terbimbing pada materi analisis kualitatif kation golongan 1,” Jurnal Inkuiri, vol. 4(3), pp. 120-126, 2015.

[9] U. A. Syed Noor, "An effective use of ICT for education and learning by drawing on worldwide knowledge, research and experience: ICT as a change agent for education (A Literature review)," Scholarly Journal of Education, vol. (2)4, pp. 38-45, April 2013. 
[10] P. A. Ertmer, and A. T. Ottenbreit-Leftwich, "Teacher Technology Change: How Knowledge, Confidence, Beliefs, and Culture Intersect," Journal of Research on Technology in Education, vol. 42(3), pp. 255284, September 2018.

[11] F. Kaleliog, "A new way of teaching programming skills to K-12 students : Code .org.," Computer in Human Behavior, vol. 52, pp. 200210, November 2015.

[12] M. Maavak, and A. S. Ariffin, "Is Malaysia Ready for the Fourth Industrial Revolution?: The Automotive Sector as an i4.0 Springboard," in Brunet-Thornton, R., \& Martinez, F. (Ed.), Analyzing the Impacts of Industry 4.0 in Modern Business Environments: IGI Global, 2018, pp. 41-64.

[13] A. P. Rehmat, H. Ehsan, and M. E. Cardella "Instructional strategies to promote computational thinking for young learners," Journal of Digital Learning in Teacher Education, vol. 36(1), pp. 46-62, February 2020.

[14] K. Samudin, K. F. Looi, and Y. M. Tham, "Asas Sains Komputer Tingkatan 1,” Percetakan Rina Sdn. Bhd, Kuala Lumpur: 2016.

[15] U. L. Ling, T. C. Saibin, J. Labadin, and N. A. Aziz, "Preliminary Investigation: Teachers' Perception on Computational Thinking Concepts," Journal of Telecommunication, Electronic and Computer Engineering, vol. 9(2), pp. 2289-8131, May 2018.

[16] S. Senin, and N. M. Nasri, "Teachers' Concern towards Applying Computational Thinking Skills in Teaching and Learning," International Journal of Academic Research in Business and Social Sciences, vol. 9(1), pp. 296-310, February 2019.

[17] U. L. Ling, C.S Tammie, N. Nasrah, L. Jane, and A. A. Norazilah, "An Evaluation Tool To Measure Computational Thinking Skills: Pilot Investigation,” Herald NAMSCA, vol. 1, pp. 606-614, September 2018.

[18] C. Samri, O. Kamisah, and A. N. Nazrul, "Level of computational thinking skills among secondary science student: Variation across gender and mathematics achievement," International Council of Association for Science Education, vol. 31(2), pp. 159-163, June 2020.

[19] R. E. Slavin, Educational Psychology: Theory And Practice, $8^{\text {th }}$ ed.,. Boston: Pearson, 2006.

[20] S. Papert, Situating constructionism, Norwood, NJ: Ablex Publishing Corporation, 1991, pp.1-28.
[21] Y. Kafai, and M. Resnick, Constructionism in practice: Designing, thinking, and learning in a digital world, Mahwah, NJ: Lawrence Erlbaum Associates, Inc., 1996.

[22] F. Kalelioğlu, and Y. Gülbahar, "The Effects of Teaching Programming via Scratch on Problem Solving Skills: A Discussion from Learners' Perspective,” Informatics in Education, vol. 13(1), pp. 33-50, January 2014.

[23] Ö. Korkmaz, and A.Oluk, “Comparing students' Scratch skills with their computational thinking skills in terms of different variables," I.J. Modern Education and Computer Science, vol. 11, pp. 1-7, November 2016.

[24] J. M. Sáez-López, M. Román-González, and E. Vázquez-Cano, "Visual programming languages integrated across the curriculum in elementary school: A two year case study using "scratch" in five schools,", Computers \& Education, vol. 97, pp. 129-141, June 2016.

[25] M. Bower, L. N. Wood, J. W. M. Lai, C. Howe, R. Lister, R. Mason, K. Highfield, and J. Veal "Improving the computational thinking pedagogical capabilities of school teachers," Australian Journal of Teacher Education, vol. 42(3), April 2017.

[26] X. Basogain, M. A. Olabe, J. C. Olabe and M. J. Rico, "Computational Thinking in pre-university Blended Learning classrooms," Computers in Human Behavior, vol. 80, pp. 412-419, March 2018.

[27] A. Alfayez, and J. Lambert, "Exploring Saudi Computer Science Teachers' Conceptual Mastery Level of Computational Thinking Skills," Computers in the Schools, vol. 36(3), pp. 143-166, August 2019.

[28] C. Kale, M. Akcaoglu, T. Cullen, D. Goh, L. Devine, N. Calvert, and K. Grise, "Computational What? Relating Computational Thinking to Teaching,” TechTrends, vol. 62 (6), pp. 574-584, November 2018.

[29] S. Atmatzidou, and S. Demetriadis, “Advancing students' computational thinking skills through educational robotics: A study on age and gender relevant differences,” Robotics and Autonomous Systems, vol. 75, pp. 661-670, January 2016.

[30] L. Shanmugam, S. F. Yassin, and F. Khalid, "Incorporating the elements of computational thinking into the Mobile Application Development Life Cycle (MADLC) model," International Journal of Engineering and Advanced Technology, vol. 8(5), pp. 815-824, June 2019. 